\title{
Trends in Ayurvedic FMCG Market
}

\author{
Vineet Sharma', Saumya Gulati ${ }^{1}$, Ashutosh Pandey ${ }^{1}$, Dev Nath Singh Gautam ${ }^{1 *}$, Himanshu ${ }^{2}$ \\ 'Department of Rasa Shastra, Faculty of Ayurveda, Institute of Medical Sciences, Banaras Hindu University, Varanasi, Uttar Pradesh, INDIA. \\ ${ }^{2}$ Department of Science and Technology-CIMS, Institute of Sciences, Banaras Hindu University, Varanasi, Uttar Pradesh, INDIA.
}

\begin{abstract}
The customer preference for over-the-counter drugs, processed food, soft drinks etc has led to reforms of the Fast-moving consumer goods (FMCG) industry. The Fast-moving consumer goods industry is growing at $4 \%$ per year, which is more than the global gross domestic product (GDP). FMCG is the fourth major sector of the Indian financial system. With the increasing speed of the Ayurvedic pharmaceutical market, FMCG players like Patanjali, Dabur, Emami etc. are interested in expanding to tap the market by their portfolios. FMCG sector is divided into food and beverages, health care and household along with personal care categories. Ayurvedic FMCG industry is based on the expansion and marketing of products between food drinks, health, domestic and personal care etc. In the current scenario, more than 30,000 proprietary and 1500 classical products are available in the market. The market of Ayurvedic FMCG products is estimated to register a compound annual growth rate (CAGR) of 16\% between 2016 and 2021 and will increase from current $\$ 500$ million to $\$ 1.1$ billion by 2021. Although many FMCG products advertise the estimated results, the Ayurvedic FMCG industry is largely irregular. Mushrooming Indian population, mainly the middle class and the rural sectors, gives a chance to
\end{abstract}

manufacturers of proprietary products to refurbish consumers to proprietary products. Consumers to take precautions are derived from caution and doubt, because the shift toward natural products has gathered momentum. In addition, companies of all sizes are racing to keep pace. This manuscript reviews a snapshot of current trends in the Ayurvedic FMCG market and will provide development opportunities and strategies adopted by the multi-billion dollar market.

Key words: Ayurvedic, CAGR, FMCG, GDP, Industry, Portfolio.

Correspondence

Dr. Dev Nath Singh Gautam, Associate Professor, Department of Rasa Shastra, Faculty of Ayurveda, Institute of Medical Sciences, Banaras Hindu University, Varanasi-221005, Uttar Pradesh, INDIA.

Phone: +919450824065

Email: drdnsgautam@gmail.com

DOI: $10.5530 /$ jyp.2019.11.28

\section{INTRODUCTION}

As a South Asian country, the population of India has grown to 1.2 billion in population growth of $1.2 \%$ in $2016 .{ }^{1}$ Indian population mainly comprises young individuals, as it was mentioned that in 2016 sixty-five per cent of its population was under 35 years of age. ${ }^{2}$ However, due to a significant decrease in life expectancy in the coming decades, there will be an increase in the population growth rate with an estimated nominal gross domestic product (GDP) of \$2.84 trillion in 2017. India is the seventh largest economy in the world. ${ }^{3}$ The country's economy depends on agriculture and services. India's current financial sector is incredible owing to the direct or indirect presence of government in various financial sectors, including manufacturing and services. ${ }^{4}$ Dr Neil H. Borden basically neologized the term FMCG, in 1965 representing products that are sold immediately and at a comparatively cheap cost. FMCG sector has enriched the fastest-growing of the household and personal care (50\%), health care (31\%) and food and beverages (19\%) segment. The FMCG sector is the fourth highest sector, growing at $4 \%$ per year, which is more than the global GDP in the Indian economy. Half of the world's population is consuming the FMCG products every day, starting from morning till the evening. The products mainly include food, tobacco, personal health care and household care. ${ }^{5,6}$ FMCG pursuits is based on consumer and market perspective. For consumer perspective, continuous purchases happen when quality, brand, knowledge, involvement and attributes of the product are known. But for the market outlook, FMCG products are in high stock with low contribution margin along with extensive distribution network and high stock turn over. ${ }^{7}$ The Ayurvedic products are being classified as proprietary and classical. At present, over 30,000 proprietary and 1500 classical products are available in the Indian market. ${ }^{8}$
Ayurvedic industries were manufacturing herbal medicines and FMCG products of more than $\$ 60$ billion per year. ${ }^{9}$ In India, the vast majority of Ayurvedic products are manufactured by regional pharmacies. Indian consumers are demanding natural products henceforth many pharmacies are launching FMCG products associated with natural ingredients. In the current scenario, the Ayurvedic medicine business only appeals to a small category of consumers. Along with awareness of health and welfare among consumers, Ayurvedic pharmacies are to enter the FMCG product segment related to health benefits. ${ }^{10,11}$ This review will provide a snapshot of current trends in the Ayurvedic FMCG market and will provide growth opportunities and strategies adopted by the multi-billion dollar market.

\section{SEGMENTS}

Currently, the FMCG sector is divided into food and beverages, health care and household along with personal care categories. Food processing (packaged foods, tea, sauces, cooking paste), health drink industry (soft drinks, fruit juices, mineral water) are coming under food and beverages segment. ${ }^{12}$ The leading market is covered by Ayurvedic FMCG industry stands with tea (hot beverage market). The tea market is dominated by unorganized players such as Twinings, Tetley, GAIA etc. Although Ayurvedic companies like Himalaya, Patanjali and Dabur, Sri SriTatva is tried to cover the leading green tea and food section. The health care sector is covered over-the-counter (OTC) products. ${ }^{13}$ OTC drugs are sold directly to consumers without any medical supervision. ${ }^{14}$ The main share of OTC drugs is dominated by leading Ayurvedic industries such as Dabur, Emami, Himalaya, Baidyanath, Patanjali etc, for example,

This is an open access article distributed under the terms of the Creative Commons Attribution-NonCommercial-ShareAlike 4.0 License, which allows others to remix, tweak, and build upon the work non-commercially, as long as the author is credited and the new creations are licensed under the identical terms. 
chyawanprash are available in many varieties depending on the choice of an individual as sugar, sugar-free and flavored. The products those are used for households such as surface cleaning agents, disinfectants, insecticides, dish cleaners, toilet cleaners and mosquito repellent. The household sector is developing in the last 5 years. ${ }^{15}$ The local and chaotic firms were headed entire volume (maximum share) of household market. Household care division is characterized by strong competition and high level of dissemination. With rapid urbanization, the presence of the small pack size and sachet, essential for home care products is thriving. ${ }^{16}$ In the washing powder area, Ayurvedic companies like Patanjali, Sri Sri Tatva, Lever Ayush is a high market share leader. Personal care areas include cosmetics, body wash, hair care, oral hygiene products, etc. The hair care market can be divided into hair oil, shampoo, gels, colourful and conditioners. In addition to personal washing can be organized in three areas viz. premium, economy and popular. The skin care market is at a primary stage in India. With lifestyle changes, new product options and availability, people are becoming more careful about personal beauty. The oral care markets are segmented into toothpaste, toothpowder and toothbrushes dominated by Dabur, Patanjali, Himalaya, Lever Ayush etc. with a high market share. ${ }^{17}$

\section{CURRENT SALES CHANNELS}

The Indian pharmaceuticals market is the $3^{\text {rd }}$ and $13^{\text {th }}$ largest in terms of volume and value respectively. ${ }^{18}$ It accounts for $20 \%$ in the volume terms and $1.4 \%$ in value terms of the global pharmaceutical industry as per a report by Equity Master. ${ }^{19}$ The current sales channel of Ayurvedic FMCG market is following (Figure 1).

\section{TRANSFORMATION IN INDIAN FMCG SECTOR}

FMCG is the fourth major sector of the Indian financial system. In 2015, the FMCG sector in India achieved profits worth $\$ 47.3$ billion. In 2016, the revenue for the FMCG sector has reached \$ 49 billion. Domestic and personal care is the most important sector, which is $50 \%$ of the total FMCG market. Health care (31\%) and food with beverage (19\%) come in the matter of market share. Hair care is the leading area, which is $23 \%$ of the wide market in terms of profits. The food sector is the next leading division of accounting for an area of $19 \%$, followed by a market share of $16 \%$ and $15 \%$ respectively of health supplements and oral care. The value of Indian cosmetics and skin care market is \$274 million and it is owned by many Ayurvedic FMCG companies. Changing awareness, easy access and changing lifestyle are important development accelerators for the segment. Growth for the expenditure of consumers, increase in rural demand and advancement of premium products are significant for the growth in the number of Ayurvedic FMCG categories. ${ }^{17}$ According to the Tech Sci Research, the market of Indian Ayurvedic FMCG products is estimated to record a CAGR of $16 \%$ between 2016 and 2021. It will increase from current $\$ 500$ million to $\$ 1.1$ billion by 2021. People are deeply embracing Ayurvedic products, which has resulted in an increase in the FMCG segment. Examples of legacy brands such as Patanjali, Dabur, Himalaya, Baidyanath, Emami, which are safely adding shelf spaces to new age disruptions. With a revenue target of ₹20,000 crore for FY 18, Patanjali Ayurveda Limited (PAL) is growing rapidly at $150 \%$ CAGR in the next 5 years. ${ }^{10}$ These disruptors have established strong capitalization on their experience in providing different preferences to the customers. The market for Ayurvedic products is estimated at ₹50,000 crore. The target of all the companies is to magnify globally in the next 5 to 10 years. ${ }^{20}$

\section{MARKET SHARE}

The urban region (revenue allocate of $60 \%$ ) is the foremost contributor to the broad revenue caused by the FMCG sector in India with the market size of about $\$ 29.4$ billion in 2016. The semi-urban and rural areas are also growing at fast speed and reported for revenue allocates

\section{Manufacturer/Marketing Organization}

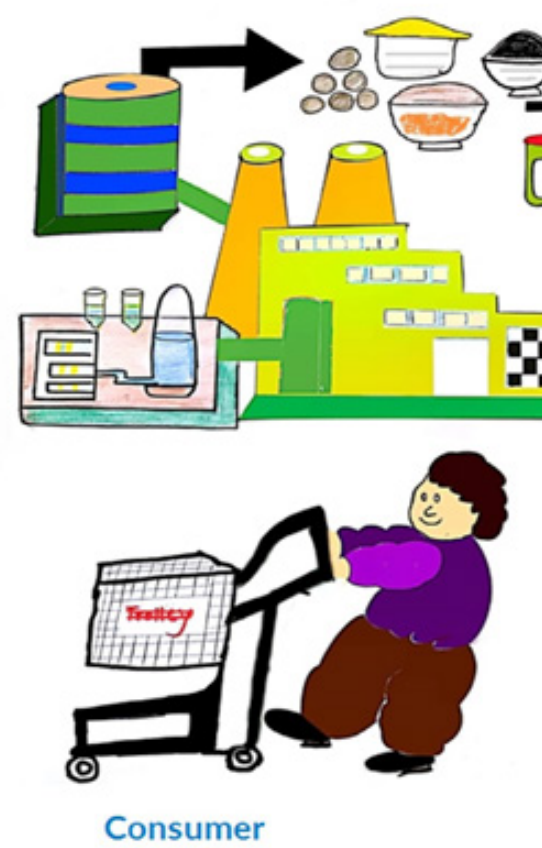

Distributor/Dealer

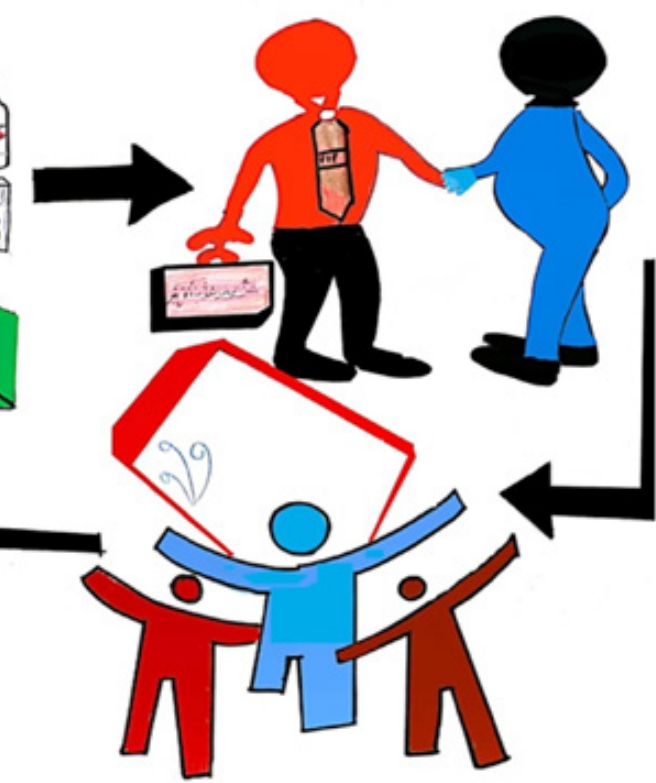

Retailer/Wholesaler/Institution

Figure 1: Current sales channels of Ayurvedic FMCG and pharma product. 
of $40 \%$. In the last few years, the Ayurvedic FMCG market in rural India is emerging quickly with urban India. Per capita, the disposable income of rural India is to mounting incessantly. As the level of income is growing, there is an obvious increase in non-food expenditure in rural India. The government announced its plans to spend $\$ 9.16$ billion for the opening of more jobs in rural areas, which in turn will increase demand for FMCG products. The rural FMCG market is supposed to rise from $17.41 \%$ to $\$ 100$ billion CAGR throughout $2009-25 .^{21}$

\section{RECENT TRENDS}

\section{Changing life style}

Approach to different pricing, improved lifestyle and chemical-free products have become the new standard for Indian consumers to get the upper hand Ayurveda. ${ }^{22}$

\section{Reinforcement}

Ayurvedic FMCG companies are integrating their accessible business portfolios which are moving towards divestments, mergers and acquisitions. The example in the Indian market, Dabur India stakes maximum Indian market share for health care category. It shows its existence in a specific herbal field. In foreign countries, Saudi Arabia and Egypt have $69 \%$ and $62 \%$ hair oil market share respectively in India. It strengthens their market power. ${ }^{23}$

\section{Premiumization}

Consumers are eager to buy premium goods at high prices on behalf of ease, health and wellness. Premiumization is actually a means of growth. In India, everyone is a candidate to be superior, earns more, uses healthy products and receives more payments. When pharma companies offer more benefits to consumers in the same product form, this premiumization is created. It's just about saying that if companies launched hair oil keep hairs moist only, it becomes the base hair oil. But if hair oil prepared to contain Ayurvedic ingredients, that prevents hair loss and provide nourishment, then all of us are ready to pay extra money for it. At current scenario, many toothpaste companies are selling their product with the badge of Ayurveda. The trend is going to be natural influencing Global as well as Indian market. Indian market is influenced at small scale, while globally people are building big storms to be natural. ${ }^{24}$

\section{Innovation}

Consumers have started demanding customized products especially in accordance with their personal taste and needs. Many Ayurvedic companies have established innovative product portfolios for a new customer. They are moving ahead through revolutionizing and improving natural products for youth. From Kwatha (for the treatment of cold and cough) in a sachet, tea sticks formats, gel toothpaste, ready-to-drink (aloe vera and amla) juice. $^{25}$

\section{Market consolidation}

Numerous companies are continuous investigating the business perspective of foreign and several regional marketplaces. Emami group seized ₹ 1,651 crores for the Rs 730 crore Kesh King brands of hair and scalp care products from Zandu Pharmaceutical and SBS Biotech in 2008. ${ }^{27,28}$ The multinational brand (HUL, ITC) has emerged to be affected. Unilever is promoting Lever Ayush with an advertisement with celebrity, who is currently piggybacking on the change of Ayurveda. In reality, Unilever is paying no attention to the multinational corporations (MNCs) eligibility for its advertising. ${ }^{29}$

\section{Network distribution}

Companies are currently focused on improving their distribution network to increase their connectivity in rural India. Patanjali and Sri SriTattva, leading Ayurvedic FMCG companies, is trying to decrease its paramount time by building its supply channel additional competent and getting retail stores directly from the manufacturing unit. ${ }^{30}$

\section{Packing systems}

For offering safety and quality products, the industries were offering active and intelligent packaging technologies. This technologies are enhanced the shelf life of products as well as safer. In addition companies are opening smaller stock-maintenance units at a lower price. This helps them maintain margin, keep the volume from price-alert customers and enhance their customer base. ${ }^{31}$

\section{Increased hiring from tier II/III cities}

A report from the Confederation of Indian Industry (CII) and the Boston Consulting Group (BCG) showed that e-commerce is participated in a major way for the development of the FMCG sector. The report recommends that companies are focusing their attention on tier II and III cities and rural areas, as purchasing power from these areas will be very tremendous. Small town and cities of India are considered to contribute more to the future demand for FMCG sector, whereas e-commerce companies will contribute to a large portion of sales for these companies. It has been said in the report that companies will need to pay attention to level II and III cities and rural areas because their profits will be an essential source of demand for the region as more and more consumers go ahead with non-branded to branded sections. ${ }^{32}$

\section{Global trend}

The acquisition of old Indian tradition has changed into harsh terms with heritage brands, although with a modest turn. Like Dabur, who has decided to take their products in the United States, Mexico and Canada with Amazon's Global Sales Program? Permission for that Dabur makes more than $30 \%$ of income from international operations. Other players like the Himalayas receive huge international revenues, which can be targeted by Dabur across amazon. ${ }^{33}$

\section{GROWTH OPPORTUNITIES}

The leading corporate of consumer products have a strong distribution network in the rural area. The internet and e-commerce technologies give an advantage to advanced logistics. Another point is that Indian consumers are tremendously flexible for pioneering Ayurvedic products because they are using them as home remedies since time for the treatment of several diseases. Henceforth, new Ayurvedic products launched in the market will be easily accepted by the population. Example flavored and drinking yogurt, flavoured Chyawanprash, fairness creams etc. In urban areas, consumers of middle and high income have necessarily transferred their purchase style from premium products due to increase in disposable income. ${ }^{34}$

\section{CONCLUSION}

The Indian market is growing at $15-20 \%$ (7,000 million or 150 million) per year. As the global demand increases 1\% (\$ 610 million) annually, the size of the export market for medicinal plants appears larger than the Indian domestic market. Per capita consumption along with saturation levels in major product categories such as toothpaste, jams, skin care, hair washing etc. generated by Ayurvedic companies. In India, these products are low indicating the untouched market attitude. Escalating Indian population, mainly the middle class and the rural sectors, gives a 
chance to manufacturers of proprietary products to renovate consumers to proprietary products. There is also a diverse agro-climatic condition which suggests the basis of suitable raw material (sugarcane, spices, milk, grains, vegetable etc) for many FMCG subdivisions, such as cosmetic as well as food processing industries in India. India is also a rich supply of caustic soda and soda ash, the most important raw material in the manufacture of shampoo, soap and detergent, which allows the domestic sector to shine and grow. This is the reason why many Ayurvedic companies are capitalizing in the food and household section. Easy accessibility of raw materials, affordable labour expenditure and presence of the full value chain provide a competitive advantage to Ayurvedic companies. The convenience of these raw materials gives an advantage to the people to find work and jobs in India. In Asian countries, labour charges are the lowest in India. The substantial cost of production is the result of the easy availability of raw material and lesser labour charges. In this way, many Ayurvedic and multinational companies have established huge low-cost fabrication bases in India for domestic expansion with export markets. Some of the trends may be seen in upcoming years like e-commerce entrance assisted by GST, aggregator driven model in food, changing lifestyles, return to Indian/ethnic styles, focus on health with taste, corporations continue to dominate, rejuvenation of Ayurvedic products by Ayurvedic FMCG industry.

\section{ABBREVIATIONS}

FMCG: Fast-moving Consumer Goods; CAGR: Compound Annual Growth Rate; GDP: Gross Domestic Product; OTC: Over-The-Counter; PAL: Patanjali Ayurveda Limited; MNC's: Multinational Corporations; CII: Confederation of Indian Industry; BCG: Boston Consulting Group; GST: Goods and Services Tax; HUL: Hindustan Unilever Limited; ITC: India Tobacco Company.

\section{REFERENCES}

1. https://data.worldbank.org, Washington: Population growth (annual \%), [updated 2017 December 05; cited 2017 Dec 05]. Available from: https://data. worldbank.Org/indicator/sp.pop.grow

2. http://censusindia.gov.in, New Delhi: Demography Division, [updated 2017 December 25; cited 2017 Dec 25]. Available from:http://censusindia.gov.in/2011common /Demography_Division.html

3. https://www.imf.org, Washington: World Economic Outlook Database. [updated 2018 January 10; cited 2018 Jan 10]. https://www.imf.org/external/ pubs/ft/ weo/ 2018/01/ weodata/index.aspx

4. Chatterjee P. Democracy and economic transformation in india. Econ Polit Wkly. 2008;43(16):53-62.

5. Shekhar SK, Raveendran PT. Promises of silent salesman to the FMCG industry: an investigation using linear discriminant analysis approach. Manag Mark. 2015;10(4):304-15

6. https://www.ibef.org/, New Delhi: India Brand Equity Foundation, [updated 2018 December, 8; cited 2007 Jul 1]. Available from: https://www.ibef.org/industry/fmcg.aspx

7. Tariq MI, Nawaz MR, Nawaz MM, Butt HA. Customer perceptions about branding and purchase intention: a study of FMCG in an emerging market. J Basic ApplSci Res. 2013;3(2):340-7.

8. Parasuraman S, Thing GS, Dhanaraj SA. Polyherbal formulation: Concept of Ayurveda.Pharmacogn Rev. 2014;8(16):73-80.

9. Sharma A, Shanker C, Tyagi LK, Singh M, Rao CV. Herbal medicine for market potential in India: an overview. Acad J Plant Sci. 2008;1(2):26-36.

10. Gupta R. Disruptive marketing and brand building: A case study of Patanjali, Ayurveda Limited. Adv Econ Bus Manag. 2016;3(2):225-31.

11. Kapoor D, Chaudhary M. Patanjali: Emergence of a new star on the Indian FMCG horizon. Indian J Mark. 2017;47(1):54-63.

12. Kerry JP. New packaging technologies, materials and formats for fast-moving consumer products. Innovations in food packaging ( $2^{\text {nd }}$ ed., pp. 549-84). San Diego, USA: Academic Press.

13. https://economictimes.indiatimes.com, Mumbai: India's tea industry is struggling to move up the value chain, [updated 2018 August 19; cited 2018 Aug 1]. Available from:https://economictimes.indiatimes.com/industry/cons-products/food/indias-tea-industry-is-struggling-to-move-up-the-value-chain/articleshow/65456045.cms

14. Blenkinsopp A, Bradley C. Over the Counter Drugs: Patients, society and the increase in self medication. BMJ. 1996;312(7031):629-32.

15. Attri R. Anju Pharmaceuticals: riding the herbal wave. Emerald Emerg Mark Case Stud. 2017;7(3):1-26.

16. Vibhuti $D$, Tyagi AK, Pandey V. A case study on consumer buying behaviour towards selected FMCG products. Int J Sci Res Manag. 2017;2(8):1168-82.

17. https://www.ibef.org/, New Delhi: India Brand Equity Foundation, [updated 2018 September, 8; cited 2007 Jul 1]. Available from: https:/ /www.ibef.org / download /FMCG -July 2017.pdf

18. Kiran R, Mishra S. Performance of the Indian pharmaceutical industry in postTRIPS period: a firm level analysis. Int Rev Bus Res Papers. 2009;5(6):148-60.

19. https://www.equitymaster.com, Mumbai: Equitymaster The investors best friend, [updated 2018 March, 26; cited 2018 Mar 26]. Available from:https:// www. equitymaster.com/research-it/sector-info/pharma/Pharmaceuticals-Sector-Analysis-Report.asp

20. https://www.techsciresearch.com/, Uttar Pradesh: Tech Sci Research from Now to next, [updated 2017 Oct 5; cited 2016 Nov 02]. Available from: https:// www.techsciresearch.com/admin/gall_content/2016/11/2016_11\$thumbimg1 02_Nov_2016_004628313.pdf

21. https://www.ibef.org/, New Delhi: India Brand Equity Foundation, [updated 2017 Jul, 8; cited 2017 Jul 8]. Available from:https://www.ibef.org/industry/ urban-market-india.aspx

22. Bagchi B, Chakrabarti J, Roy PB. Influence of working capital management on profitability: a study on Indian FMCG companies. Int J Bus Manag. 2012;7(22):1 10.

23. Sreejith R, Suresh K. The Patanjali Marketing Sutra-an Exploratory Analysis of Brand Experience, Personality, Satisfaction and Loyalty in the FMCG Space. IndianJ Mark. 2017;47(9):36-48.

24. Ahmed JU, Sultana H, Ahmed A. Patanjali ayurved invades India. Decision. 2018:45(1):75-91.

25. Pandey P, Sah R. Growth of Swadeshi-A Case Study on Patanjali Ayurved Limited. Int J Eng Tech Manag Appl Sci. 2016;4(7):7-14.

26. http://www.business-standard.com/article/companies/emami-infra-to-mergerealty-arm-with-itself-to-unlock-value-fund-projects-117071000795_1.html

27. https://economictimes.indiatimes.com, Mumbai: Emami gets into haircare, acquires Kesh King for Rs 1,651 crore, [updated 2015 Jun 03; cited 2015 Jun 03] Available from:https://economictimes.indiatimes.com/industry/cons-products/ fmcg/emami-gets-into-haircare-acquires-kesh-king-for-rs-1651-crore/articleshow/47511613.cms

28. https://economictimes.indiatimes.com, Mumbai: Emami plans to merge Zandu, announces management rejig, [updated 2008 Dec 01; cited 2008 Dec 01] Available from: https://economictimes.indiatimes.com/industry/cons-products/ fmcg/emami-plans-to-merge-zandu-announces-management-rejig/articleshow/3781356.cms

29. https://www.business-standard.com, Mumbai: Akshay Kumar to be the face of Ayurvedic personal care brand, [updated 2017 Aug 02; cited 2017 Aug 02] Available from: https://www.business-standard.com/article/news-ians/akshaykumar-to-be-face-of-ayurvedic-personal-care-brand-117080200846_1.html

30. Gaur S, Nimit G. Disruptive Patanjali: Changing the Indian FMCG Landscape. FIIB Bus Rev. 2016;5(5):55-64.

31. Biji KB, Ravishankar CN, Mohan CO, Gopal TS. Smart packaging systems for food applications: a review. J Food Sci Tech. 2015;52(10):6125-35.

32. Jain R, Kulhar M. Growth Drivers of Online Shopping in Small Cities of India. Int J Adv Res ComputSci Manag Stud. 2015;3(9):80-7.

33. Goyal AP, Bagga T, Bansa S. Impact of increasing trend of online marketing on consumer buying behaviour: FMCG brands in Indian scenario. Int $\mathrm{J}$ Eng Tech Manag Appl Sci. 2016;4(5):218-29.

34. https://economictimes.indiatimes.com, Mumbai: Why companies like HUL, Patanjali, Dabur are taking a crack at the market for ayurvedic and herbal products, [updated 2017 Oct 05; cited 2017 Oct 05]. Available from: https://economic times.indiatimes.com/industry/cons-products/fmcg/why-companies-like-hulpatanjali-dabur-are-taking-a-crack-at-the-market-for-ayurvedic-and-herbal-products/articleshow/61084207.cms

Article History: Submission Date : 24-10-2018; Revised Date : 03-01-2019; Acceptance Date : 25-01-2019

Cite this article: Sharma V, Gulati S, Pandey A, Gautam DNS, Himanshu. Trends in Ayurvedic FMCG Market. J Young Pharm. 2019;11(2):126-9. 